\title{
The Influence of Institutional Ownership, Asset Structure, and Company Size on Debt Policy (Empirical Study on Food and Beverages Sub-Sector Companies Listed on the Indonesia Stock Exchange)
}

\author{
Hengky Leon \\ Email: hengkyleon11@gmail.com \\ ${ }^{1}$ Widya Dharma University Pontianak, Indonesia \\ Received: December 8, 2021 \\ Revised: January 18, 2022 \\ Accepted: January 27, 2022
}

\begin{abstract}
Debt policy is one part of the policy in determining funding for the company in financing every activity of operations. With the obligations within the company, it is expected to reduce the control exercised by managers on the company's cash flow arrangements. The purpose of the research is to measure the implementation of institutional ownership, asset structure, and company size against debt policy on the food and beverages company was listed on the Indonesia stock exchange. The size that is used consists of institutional ownership percentage, comparison between fixed assets to total assets, natural logarithm of total assets and debt ratio. Analysis tools are used in the research using the SPSS program. Method of determination of samples is sensus sampling where there are 54 observation data. The analysis used in the SPSS program is descriptive analysis, normality test, multicollinearity test, heteroscedasticity test, autocorrelation test, multiple linear regression, correlation and determination test, $\mathrm{f}$ test, and ttest. As for the results of the research conducted is a regression model already are BLUE and have a specification of goodness fit model. Institutional ownership has no effect against debt policy, asset structure of influential positively against debt policy, and company size of influential negatively against debt policy.
\end{abstract}

Keywords: Intitutional Ownership, Asset Structure, Company Size dan Debt Policy

\section{Introduction}

Debt Policy is one part of the policy in determining funding for companies to finance each of their operational activities. Debt is a sacrifice of economic benefits in the future that may occur due to the fulfillment of obligations by a business entity at this time to transfer assets or provide services to other business entities in the future as a result of transactions or events in the future. With debts to food and beverages companies, companies are required to make periodic principal and interest payments. The existence of these obligations is expected to reduce the control exercised by managers over the company's cash flow arrangements (Flodén et al., 2021).

This research was conducted based on the development of previous research conducted by Astuti (2014) \& Trisnawati (2016). The difference between this research and previous research is that it focuses on one object of research that uses the Food and Beverages Sub-Sector Listed on the Indonesia Stock Exchange. In addition, the researcher also uses the 2019-2020 period and uses a different formula for determining the debt policy that has been carried out by previous researchers and to test how much influence there is between Institutional Ownership, Asset Structure and Company Size on Debt Policy. This test was carried out to see if there were differences in the results carried out by both the researcher and the previous researchers. 


\section{Theoretical Study}

\section{Agency Theory}

Jensen \& Meckling (1976) stated that "agency relationship as a contract under which one or more person (the principal(s)) engage another person (the agent) to perform some service on their behalf which involves delegating some decision-making authority to the agent. If both parties to the relationship are utility maximizers, there is good reason to believe that the agent will not always act in the best interest of the principal." Purba (2009) defines agency relationship as the relationship between shareholders and company directors. The interests of company directors and shareholders are not the same and often conflict. Harmono (2011) states that agency theory shows that incomplete and uncertain information conditions will lead to agency problems, namely adverse selection and moral hazard. Adverse selection is a condition that shows the position of the principal does not get accurate information about the performance of management who has determined the payment of salaries for management or other compensation programs. Moral hazard is related to the condition of the principal not getting certainty that management has tried to work as much as possible for the interests of the owner (Gundersonet al., 2019). Agency costs are costs incurred related to the form of management supervision based on cooperation contracts by shareholders (Campos-Alba et al., 2020; Canitez et al., 2019; Harjito \& Martono, 2012)

\section{Pecking Order Theory}

Pecking Order Theory states that companies that have a high level of profitability will make a low debt rating. This is because companies that have a high profitability value will have abundant internal sources of funds due to profit. If the profit is maximized, the company will choose the use of sources of funds originating from the company's internal first compared to sources of funds originating from external companies. Thus, the risk in using debt will be minimal due to the low level of debt. In addition, companies can implement policies in the form of seeking additional funds by selling their assets. Assets that can be sold can be in the form of land, buildings, machinery, equipment, or other assets, including by issuing or selling shares in the capital market (Fahmi, 2017).

\section{Influence of Institutional Ownership on Debt Policy}

Institutional Ownership has a controlling role in an entity. Thus, institutional ownership tries to maintain business continuity through its role at the General Meeting of Shareholders (GMS) in order to minimize the use of debt policy. If the debt policy has a low value, the company will avoid financial problems and can maximize the profit, firm value and returns expected by institutional ownership. This research is in line with Trisnawati's (2016) research which states that institutional ownership has a negative effect on debt policy. However, this study is not in line with research by Astuti (2014) which states that institutional ownership has no effect on debt policy. Based on the description that has been described, the researcher proposes the following hypothesis:

\section{H1: Institutional Ownership has a negative effect on Debt Policy}

\section{Effect of Asset Structure on Debt Policy}

The Asset Structure shows the composition of the company's wealth distribution that can be used as collateral in the use of debt by the company. What can be guaranteed is the use of fixed assets that have a value that is capable or comparable to be used as collateral for the use of debt. The greater the value of fixed assets that become collateral, the greater the use of debt policy. If the debt policy has a higher value, the company has additional funds for operational development and company expansion that come from funds from outside the company. This

Copyright $\odot$ 2022, Journal of Asian Multicultural Research for Economy and Management Study, Under the license CC BY-SA 4.0 
research is in line with Trisnawati's (2016) research which states that asset structure has a positive effect on debt policy. Based on the description that has been described, the researcher proposes the following hypothesis:

H2: Asset Structure has a positive effect on Debt Policy

\section{The Influence of Company Size on Debt Policy}

Company Size is one of the basic measurements related to debt policy. This is because a large company has diversification in both business and product branches, it is easier to enter the capital market, and it is easier to accept higher credit ratings by commercial banks. In addition, companies with large sizes have assets of large and comparable value to serve as collateral for loans that can increase the value of the debt policy. If the debt policy has a higher value, the company will be able to provide convenience for the use of the debt policy due to the large size of the company so that it can provide clarity regarding credit trust and promising survival. This study is in line with research by Astuti (2014) which states that firm size has a positive effect on debt policy. However, this study is not in line with Trisnawati's (2016) research which states that firm size has no effect on debt policy. Based on the description that has been described, the researcher proposes the following hypothesis: H3: Company Size has a positive effect on Debt Policy.

\section{Methods}

\section{Research Samples and Data}

The form of research is associative method. The author uses three independent variables, namely institutional ownership, asset structure, and company size and one dependent variable, namely debt policy. The research object used is the food and beverages sub-sector companies listed on the Indonesia Stock Exchange during the 2019-2020 period. The selection of data is based on the total population of companies in the food and beverages sub-sector because the data for the entire population is complete so that the sample selection uses census sampling. The number of food and beverages sub-sector companies listed on the Indonesia Stock Exchange are 27 companies with a total of 54 observational data.

\section{Variable Identification}

\section{Debt Policy}

The definition of a debt policy is the determination of decisions in the form of actions taken by company management to fund business operations with sources of funds obtained from outside the company in the form of borrowing funds through debt. With this policy, it is hoped that the company can develop its business into a large-sized business, become more successful and increase trust in creditors and stakeholders by building good corporate value. This policy is very important because this policy regulates the acquisition of funding sources that are broad and not only obtained from within the company. However, this can be a risky decision because if there is an error in managing debt, it will raise the risk of financial problems (financial distress) which can end in the bankruptcy of a company. Debt policy can be proxied using one of the solvency ratios, namely the debt ratio. Debt ratio or debt ratio is one of the ratios that can be used to evaluate how much the company's wealth is financed or guaranteed by debt. This ratio takes into account all debt with all maturing obligations of all creditors guaranteed or financed by the total wealth owned by the company. Kasmir (2010) states that the debt ratio (DAR) is explained by the following formula:

$$
D A R=\frac{\text { Total Liabilities }}{\text { Total Asset }}
$$




\section{Institutional Ownership}

The definition of institutional ownership is ownership held by institutional investors such as pension funds, insurance companies, investment companies, commercial banks and savings institutions. Gunawan (2021) states that institutional ownership is better than individual ownership because institutional ownership has the power to take over the direction of work which is less effective and efficient. With a high percentage of institutional ownership, stock investors can help direct management actions so that they are in line with what is expected. Institutional ownership has a greater willingness to transfer funds beyond national boundaries to improve the opportunity risk of returns from portfolios that include financial assets from foreign issuers. To determine the identification of institutional ownership variables, the percentage of institutional ownership in the food and beverages sub-sector companies listed on the Indonesia Stock Exchange is used. Institutional ownership is explained by the following formula:

$$
I N S=\frac{\text { Number of shares held by institutional }+ \text { blockholder }}{\text { Number of shares outstanding }}
$$

\section{Asset Structure}

The definition of an asset structure is a balance or comparison between current assets and fixed assets in the form of absolute value and relative value. Sujarweni (2015) concludes that the asset structure comes from how much is the allocation for the components of each asset, both current assets and fixed assets. The role of this asset structure is very important. If the company wants to obtain additional funds from outside the company for operational development and investment, it is very necessary to know the percentage of the asset structure. With a high percentage level of asset structure, the provision of guarantees in the form of fixed assets can be maximized as a form of trust in creditors. To determine the identification of the asset structure variable, we use a comparison between fixed assets and total assets in the food and beverages sub-sector companies listed on the Indonesia Stock Exchange. The asset structure is explained by the following formula:

$$
A S=\frac{\text { Aset Tetap }}{\text { Total Aset }}
$$

\section{Company Size}

The definition of company size is a measurement of the size of a company in various ways that can be done, including using the company's total assets, stock market value, total income and so on (Hery, 2017). If a company has a large size, the company will need large capital or funds to manage operations and investments. Thus, the funds obtained from within the company, namely the profit on company operations and retained earnings, may not necessarily be sufficient to balance the composition of a large company. So, debt policy also needs to be considered in determining this. The decision in determining the debt policy must be considered carefully because if the company uses debt, the company is obliged to pay principal and interest on time in accordance with the shape of a large company image. To determine the identification of the company size variable, the results of the natural logarithm of the total assets in the food and beverages sub-sector companies listed on the Indonesia Stock Exchange are used. Company size is explained by the following formula:

$$
\text { SIZE = logarithm natural total assets }
$$

\section{Results and Discussion}


The statistical results described by the researcher are described in the form of descriptive statistical analysis presented in Table 1, which describes the description of the observation data in the form of the amount of data studied, the minimum value of each variable, the maximum value of each variable, the average value of each variable and the size of the data spread from each variable.

Table 1. Descriptive Statistical Analysis

Descriptive Statistics

\begin{tabular}{|l|r|r|r|r|r|}
\hline & N & Minimum & Maximum & \multicolumn{1}{c|}{ Mean } & $\begin{array}{c}\text { Std. } \\
\text { Deviation }\end{array}$ \\
\hline DAR & 54 &, 0651 & 8,2077 &, 618167 & 1,1121787 \\
INS & 54 &, 0933 &, 9152 &, 482148 &, 2380558 \\
AS & 54 &, 0934 &, 9601 &, 553683 &, 2119446 \\
SIZE & 54 & 22,6411 & 32,7256 & 28,041324 & 1,8850194 \\
Valid N & 54 & & & & \\
(listwise) & & & & & \\
\hline
\end{tabular}

Regression models are referred to as good models if they meet the classical assumption test in the form of normality tests, multicollinearity tests, heteroskedasticity tests and autocorrelation tests.

Table 2. Normality Test

\section{One-Sample Kolmogorov-Smirnov Test}

\begin{tabular}{|c|c|c|}
\hline & & $\begin{array}{l}\text { Unstandardiz } \\
\text { ed Residual }\end{array}$ \\
\hline \multicolumn{2}{|l|}{$\mathrm{N}$} & 54 \\
\hline & Mean & $0 \mathrm{E}-7$ \\
\hline Normal Parameters ${ }^{\mathrm{a}, \mathrm{b}}$ & $\begin{array}{l}\text { Std. } \\
\text { Deviation }\end{array}$ & ,90522462 \\
\hline \multirow{3}{*}{$\begin{array}{l}\text { Most Extreme } \\
\text { Differences }\end{array}$} & Absolute & 176 \\
\hline & Positive & , 176 \\
\hline & Negative &,- 127 \\
\hline \multicolumn{2}{|l|}{ Kolmogorov-Smirnov Z } & 1,291 \\
\hline \multicolumn{2}{|l|}{ Asymp. Sig. (2-tailed) } &, 072 \\
\hline
\end{tabular}

a. Test distribution is Normal.

b. Calculated from data.

Table 3. Multicollinearity Test

\begin{tabular}{|ll|r|r|}
\hline \multicolumn{1}{|l|}{ Model } & \multicolumn{2}{|c|}{$\begin{array}{c}\text { Collinearity } \\
\text { Statistics }\end{array}$} \\
\cline { 3 - 4 } & & Tolerance & \multicolumn{1}{c|}{ VIF } \\
\hline \multirow{4}{*}{1} & (Constant) & & \\
& INS &, 932 & 1,073 \\
& AS &, 963 & 1,039 \\
& SIZE &, 954 & 1,048 \\
\hline
\end{tabular}

a.Dependent Variable: DAR

Table 4. Heteroskedasticity Test

\section{Correlations}




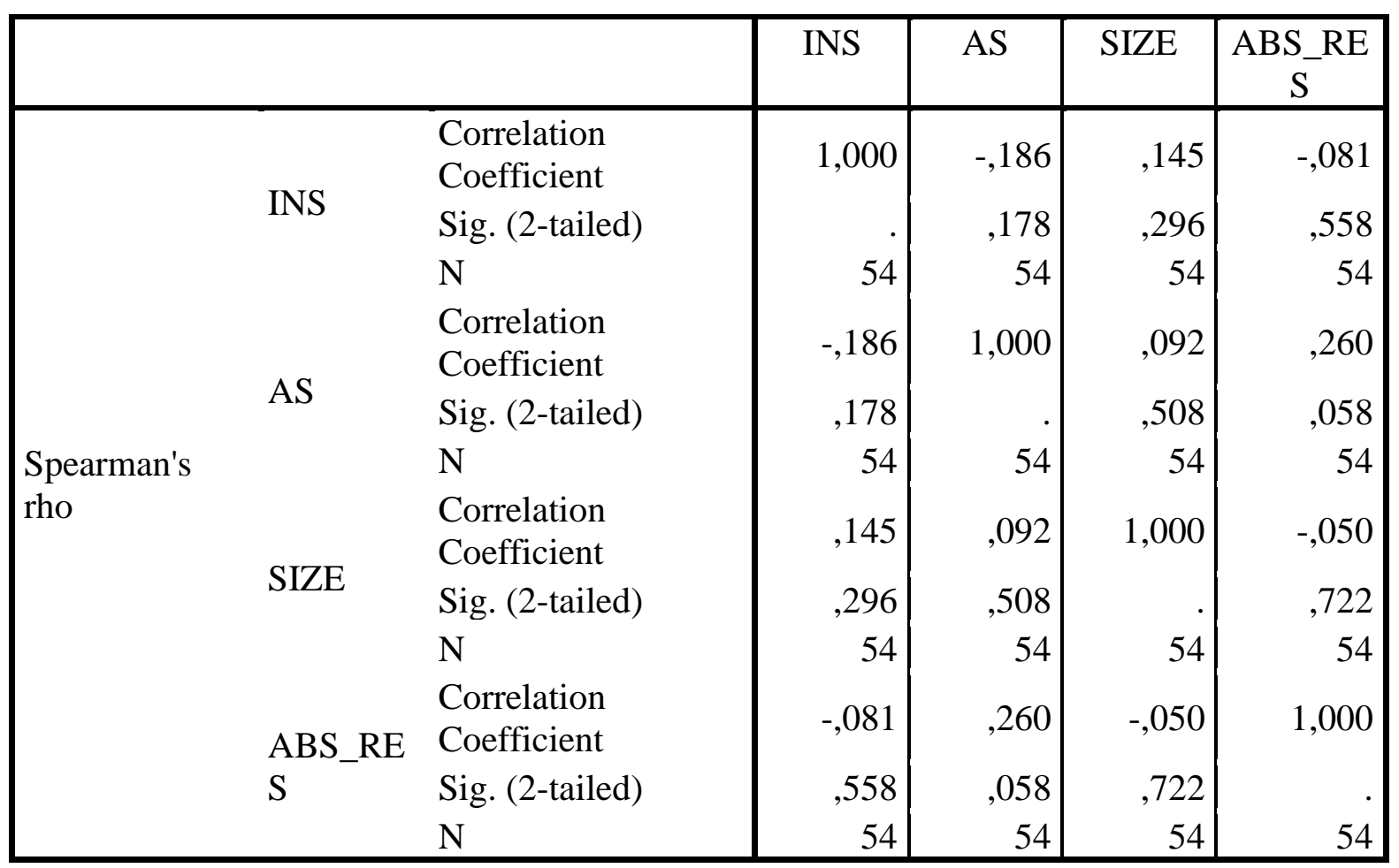

Table 5. Autocorrelation Test

Model Summary ${ }^{b}$

\begin{tabular}{|l|r|r|r|r|r|}
\hline $\begin{array}{l}\text { Mode } \\
1\end{array}$ & R & R Square & $\begin{array}{c}\text { Adjusted R } \\
\text { Square }\end{array}$ & $\begin{array}{l}\text { Std. Error of } \\
\text { the Estimate }\end{array}$ & $\begin{array}{c}\text { Durbin- } \\
\text { Watson }\end{array}$ \\
\hline 1 &, $581^{\mathrm{a}}$ &, 338 &, 298 &, 9319858 & 1,980 \\
\hline
\end{tabular}

a. Predictors: (Constant), SIZE, AS, INS

b. Dependent Variable: DAR

The classical assumption test that must be met in the linear regression model is that the residuals are normally distributed, there is no multicollinearity, there is no heteroscedasticity, and there is no autocorrelation in the regression model so that the results of the regression analysis can be said to be BLUE (best linear unbiased estimator). residuals were normally distributed $(0.072$ $>0.05)$, the independent variable did not occur multicollinearity $(0.932>0.1 ; 0.963>0.1$; $0.954>0.1)$ and $(1.073<10 ; 1.039<10 ; 1.048<10)$, the regression model did not experience heteroscedasticity $(0.558>0.05 ; 0.058>0.05 ; 0.722>0.05)$, and the regression model did not have autocorrelation $(1.680<1.980<2.320)$.

\section{Table 6. Test F}

ANOVA ${ }^{a}$

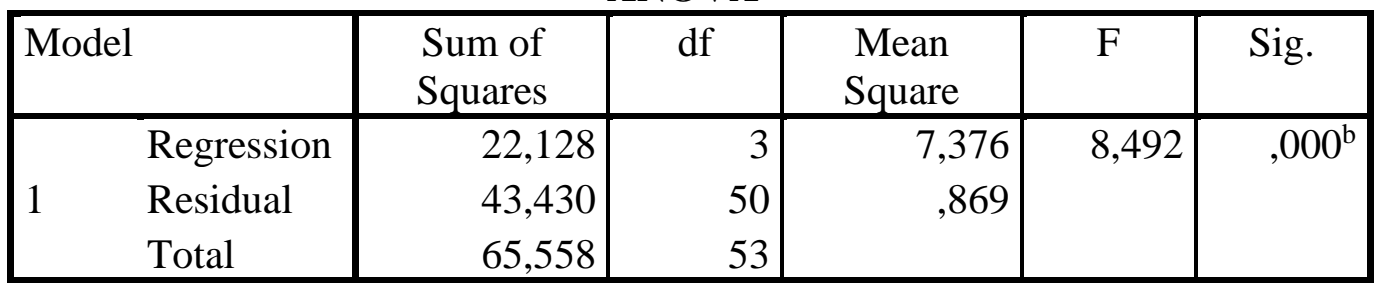

a. Dependent Variable: DAR

b. Predictors: (Constant), SIZE, AS, INS

The $\mathrm{F}$ test or the feasibility test of the regression model is used to determine the specification of the feasibility of the regression model (goodness of fit model test) where the regression

Copyright $@$ 2022, Journal of Asian Multicultural Research for Economy and Management Study, 
model is in good form or not. In this case, to find out whether institutional ownership, asset structure, and company size variables have an effect on debt policy. The test results concluded that the regression model already has a good regression model feasibility specification (goodness of fit model test). This can be seen in the significance value in Table 6 which has a value below 0.05 . In this case, the significance value for the regression model is $0.00<0.05$.

Table 7. Correlation and Determination Coefficient

Model Summary ${ }^{b}$

\begin{tabular}{|l|r|r|r|r|}
\hline $\begin{array}{l}\text { Mode } \\
1\end{array}$ & R & R Square & $\begin{array}{c}\text { Adjusted R } \\
\text { Square }\end{array}$ & $\begin{array}{r}\text { Std. Error of } \\
\text { the Estimate }\end{array}$ \\
\hline 1 &, $581^{\mathrm{a}}$ &, 338 &, 298 &, 9319858 \\
\hline
\end{tabular}

a. Predictors: (Constant), SIZE, AS, INS

b. Dependent Variable: DAR

The correlation coefficient test is used to determine the strength of the relationship between the independent variable and the dependent variable. In this case, to determine the strength of the relationship between institutional ownership, asset structure, and company size variables on debt policy. The test results concluded that the independent variable to the dependent has a strong and aligned relationship with the $\mathrm{R}$ value of 0.581 . The coefficient of determination test is used to determine the proportion of variation in the dependent variable that can be predicted from the dependent variable. In this case, to determine the proportion of institutional ownership, asset structure, and company size variations on debt policy. The test results concluded that the proportion of variation in the dependent variable that could be predicted from the dependent variable was the adjusted $\mathrm{R}$ square value of 0.298 . Thus, the proportion of variations in the debt policy variable can be predicted from the institutional ownership, asset structure, and company size variables by 29.80 percent and the remaining 70.20 percent outside of the research model discussed by the author.

Table 8. Multiple Regression Analysis

Coefficients $^{\mathrm{a}}$

\begin{tabular}{|ll|r|r|r|r|r|}
\hline \multicolumn{1}{|l|}{ Model } & \multicolumn{2}{|c|}{$\begin{array}{c}\text { Unstandardized } \\
\text { Coefficients }\end{array}$} & $\begin{array}{c}\text { Standardized } \\
\text { Coefficients }\end{array}$ & \multirow{2}{*}{ Sig. } \\
\cline { 2 - 5 } & \multicolumn{1}{c|}{ B } & Std. Error & \multicolumn{1}{c|}{ Beta } & & \\
\hline \multirow{4}{*}{1} & (Constant) & 6,760 & 1,921 & & 3,518 &, 001 \\
& INS &,- 650 &, 557 &,- 139 & $-1,167$ &, 249 \\
& AS & 1,868 &, 616 &, 356 & 3,035 &, 004 \\
& SIZE &,- 245 &, 070 &,- 415 & $-3,520$ &, 001 \\
\hline
\end{tabular}

a. Dependent Variable: DAR

The significance test is used to determine whether the independent variable has an effect on the dependent variable. The significance test is considered to have an effect if the significance value is less than 0.05 in the form of positive and negative regression coefficients, otherwise if the significance value is greater than 0.05 in the form of positive and negative regression coefficients, it will be considered to have no effect. In Table 8, the multiple regression equations are described as follows:

$$
Y^{\prime}=6,760-0,650 x_{1}+1,868 x_{2}-0,245 x_{3}
$$

The equation has a meaning which is explained as follows; (a) Nis constant (a) of 6,760 which means if institutional ownership, asset structure, and company size are worth zero then the debt policy is worth 6,760 or $676 \%$; (b) The regression coefficient value of the institutional

Copyright $\odot$ 2022, Journal of Asian Multicultural Research for Economy and Management Study, Under the license CC BY-SA 4.0 
ownership variable $\left(\mathrm{b}_{1}\right)$ of -0.650 which means that any increase in institutional ownership by $1 \%$ assuming other independent variables the value remains (unchanged), then the debt policy willdecrease by 0,650 or $65 \%$; (c) The regression coefficient value of the asset structure variable (b2)is 1.868 which means that any increase in the asset structure by $1 \%$ assuming other independent variables the value remains (unchanged), then the debt policy will increase by 1,868 or $186,8 \%$; (d) The regression coefficient value of the company size variable (b3)of -0.245 which means that any increase in company size by $1 \%$ assuming other independent variables the value remains (unchanged), then the debt policy willdecrease by 0,245 or $24.5 \%$.

From Table 8, it can be concluded that institutional ownership has no effect on debt policy (the first hypothesis is rejected). This is because the significance value $>0.05$ is equal to $(0.249>$ $0.05)$ with a regression coefficient of -0.650 . The results of this study have the same answer as Astuti's research (2014) but have the opposite answer with Trisnawati's (2016) research. From Table 8 , it can be concluded that the asset structure has a positive effect on debt policy (the second hypothesis is accepted). This is because the significance value $<0.05$ is equal to $(0.004$ $<0.05$ with a regression coefficient of 1.868). The results of this study have the same answer as Trisnawati's (2016) research. From Table 8, it can be concluded that company size has a negative effect on debt policy (the third hypothesis is rejected). This is because the significance value $<0.05$ is equal to $(0.001<0.05$ with a regression coefficient of -0.245$)$. The results of this study have an inversely proportional answer to the research of Astuti (2014) and Trisnawati (2016).

\section{Conclusion}

Research on the effect of institutional ownership, asset structure, and company size on debt policy in food and beverages sub-sector companies during the 2019-2020 period described in the regression model is already BLUE (best linear unbiased estimator) because the regression model tested already has a distributed model. normal, the model does not experience multicollinearity, heteroscedasticity and autocorrelation problems. In the F test test, the regression model already has a good regression model feasibility specification (goodness of fit model test) because the significance value is $0.00<0.05$. In testing the first hypothesis test, institutional ownership has no effect on debt policy in food and beverages sub-sector companies during the 2019-2020 period. So the first hypothesis is rejected. The results of this study support the answers to research conducted by Astuti (2014) but do not support the answers to research conducted by Trisnawati (2016). This is because institutional ownership owned by this sub-sector has not been able to influence debt policy.

In testing the second hypothesis test, asset structure has a positive effect on debt policy in food and beverages sub-sector companies during the 2019-2020 period. Then the second hypothesis is accepted. The results of this study support the answers to research conducted by Trisnawati (2016). This is influenced by the asset structure of the food and beverages sub-sector companies listed on the IDX which have a role in determining the role of debt policy. Share given in the form of embodiment of the composition of fixed assets which is used as a determination of the use of debt that is capable or comparable as collateral as a form of company trust to creditors. In testing the third hypothesis test, company size has a negative effect on debt policy in food and beverages sub-sector companies during the 2019-2020 period. Then the third hypothesis is rejected. The results of this study do not support the answers to research conducted by Astuti (2014) and Trisnawati (2016). This is influenced by the company size in the food and beverages sub-sector companies listed on the IDX which have a role in determining debt policy. The share given in the form of the embodiment of a large company size is not a consideration in determining the use of debt given by creditors because a large company size does not

Copyright $\odot$ 2022, Journal of Asian Multicultural Research for Economy and Management Study, Under the license CC BY-SA 4.0 
necessarily guarantee that debt and interest payments will run smoothly or stable according to the size of the company.

\section{Limitations and Recommendations}

The limitations of this study are as follows (1) the research model is only able to predict variations in debt policy by 29.80 percent and the remaining 70.20 percent is outside the research model discussed by the author; (2) The research focuses on only one sub-sector, namely food and beverages companies listed on the Indonesia Stock Exchange; (3) Analysis of the data period for only two years, namely the 2019-2020 period. Recommendations that can be given for the development of this research are as follows: (1) Companies can consider the use of asset structure and company size in determining debt policy. This is because the asset structure can be used as collateral for the use of debt by the company and the company size can be used to suppress the use of debt by the company; (2) Further researchers can develop research using data from different sectors, such as the energy sector or the industrial sector or the raw goods sector to see the role of debt policy shown in the financial statements of the sector; (3) Further researchers can develop research with a larger number of years, for example four years or five years to monitor the movement of indications of debt policy in depth.

\section{References}

Astuti, E. (2014). Pengaruh Kepemilikan Institusional, Profitabilitas, Ukuran Perusahaan Terhadap Kebijakan Hutang Perusahaan di Indonesia. Jurnal Akuntansi dan Pajak, STIE AAS, 15(2), 149-159.

Campos-Alba, C. M., Prior, D., Pérez-López, G., \& Zafra-Gómez, J. L. (2020). Long-term cost efficiency of alternative management forms for urban public transport from the public sector perspective. Transport Policy, 88, 16-23.

Canitez, F., Alpkokin, P., \& Black, J. A. (2019). Agency costs in public transport systems: Netcost contracting between the transport authority and private operators-impact on passengers. Cities, 86, 154-166.

Fahmi, I. (2017). Analisis Kinerja Keuangan: Bandung. Alfabeta.

Flodén, M., Kilström, M., Sigurdsson, J., \& Vestman, R. (2021). Household Debt and Monetary Policy: Revealing the Cash-Flow Channel. The Economic Journal, 131(636), 1742-1771.

Gunawan, R. M. B. (2016). GRC (Good Governance, Risk Management and Compliance). Jakarta: PT RajaGrafindo Persada.

Gunderson, R., Stuart, D., \& Petersen, B. (2019). The political economy of geoengineering as plan B: Technological rationality, moral hazard, and new technology. New Political Economy, 24(5), 696-715.

Harjito, A. \& Martono. (2012). Manajemen Keuangan, edisi ke 2. Yogyakarta: Ekonisia.

Harmono. (2011). Manajemen Keuangan Berbasis Balance Scorecard. Jakarta: PT Bumi Aksara.

Hery. (2017). Kajian Riset Akuntansi. Jakarta: Grasindo.

Jensen, M. C. \& Meckling, W. H. (1976). Theory of Firm: Managerial Behavior, Agency Cost and Ownership Structure. Journal of Financial Economics, 3(14), 305-360.

Kasmir. (2010). Pengantar Manajemen Keuangan, edisi ke 2. Jakarta: Prenadamedia Group.

Purba, M. P. (2009). Asumsi Going Concern.Yogyakarta: Graha Ilmu

Copyright $\odot$ 2022, Journal of Asian Multicultural Research for Economy and Management Study,

Under the license CC BY-SA 4.0 
Sujarweni, V. W. (2015). Metodologi Penelitian Bisnis dan Ekonomi. Yogyakarta: Pustaka Baru Pres.

Trisnawati, I. (2016). Faktor-Faktor Yang Mempengaruhi Kebijakan Hutang Pada Perusahaan Non-Keuangan Yang Terdaftar di Bursa Efek Indonesia. Jurnal Bisnis dan Akuntansi, 18(1), 33-42. 